\title{
НЕФОРМАЛЬНІ СОЦІОКУЛЬТУРНІ ІНКОРПОРАЦІЇ ОСВІТЯН У ФОКУСІ ІСТОРИЧНИХ ПОДІЙ ПЕРШОГО ТРИДЦЯТИРІЧЧЯ ХІХ СТОЛІТТЯ
}

TETIANA DUDKA, Professor of the Department of Management and Innovative Technologies, Social and Cultural Activities National Pedagogical Dragomanov University, Ukraine

\section{INFORMAL SOCIAL AND CULTURAL INCORPORATIONS OF EDUCATORS IN TERMS OF HISTORICAL EVENTS OF THE FIRST THIRTY YEARS OF THE XIX CENTURY}

\begin{abstract}
У статті здійснений аналіз впливу діяльності соціокультурних інкорпорацій освітян на розвиток регіонального просвітництва Правобережжя протягом першого тридцятиріччя XIX століття. Узагальнено значущість впливу на зорієнтованість просвітницьких проєктів соціокультурних інкорпорацій освітян суспільно-політичних, економічних та культурних детермінант досліджуваного періоду. Підкреслено, що внаслідок перехресного впливу на суспільне життя правобережних теренів полонізаційного та русифікаційного векторів свідомі представники соціокультурних інкорпорацій освітян не припиняли боротьби з наслідками шовінізму. Проблематизовано фундаментальність закономірностей культуротворчої активності соціокультурних інкорпорацій освітян, віддзеркалену на рівні розширення кількості соціальних контактів, популяризації розумової (інтелектуальної), педагогічної, науководослідницької, творчої діяльності.

Ключові слова: соціокультурна інкорпорація, освітяни, регіональне просвітництво.
\end{abstract}

Summary. The subject of the article is focused on the analysis of the issue of the personality self-realization is dictated by the necessity to turn to the progressive pedagogical experience of the previous epochs, which opens wide opportunities for rethinking the advancement of contemporary issues

(C) Т. Дудка and prospects of education.

In these circumstances, progressive scientific and pedagogical intellectuals have made considerable efforts to ensure that local educational centers help preserve national orientation in the context of adaptation to international conditions, become the basis of national socialization and identification by attracting the young generation to national cultural values.

The general imperial direction was considered the only "right" and all the contradictory points were deleted from the agenda, which proved the excessive intensification of the government's efforts to create a fake landscape of social and cultural success.

Under such ambiguous conditions of social and political existence, the real elitism of the pedagogical staff was hidden in the functional and value potential of everyday realities. The functional potential was manifested in the fulfillment of academic and educational functions on the ground and was distinguished by clear subjectsubject cooperation. The value potential was the consequence of the functional "capacity" and was reflected in the values of the academic and educational process, which "touched" each pupil's personality.

Key words: social and cultural incorporation, educators, regional enlightenment.

Мета: проаналізувати вплив неформальних соціокультурних інкорпорацій освітян на пожвавлення просвітницького руху в першому трид- цятиріччі XIX століття.

Постановка проблеми в загальному вигляді. У царині історико-педагогічних пошуків особливою цінністю вирізняються дослідження просвітницьких ініціатив, які червоними нитками вплелися у багатотомник вітчизняної історії. Історична репродукція знакових в історії просвітницько-центрованих подій наближає нас до розуміння пріоритетності особистісного фактора в соціокультурних перетвореннях, які стали доленосними на канві подальшого державотворення.

Історичні вихори почерговості наявних ліберально-консервативних курсів діючої влади не в змозі були зруйнувати міцного стрижня вітчизняних соціокультурних інкорпорацій освітян, які досить успішно функціонували в режимі неформальних ініціатив. Їх випереджувальний соціокультурний характер поцеглинно закладав міцні підвалини освітнього поступу, актуалізував підвищення загального рівня освіченості та продукував безперешкодність націєтворення.

Новітній історико-педагогічний ренесанс попередніх неформальних соціокультурних інкорпорацій освітян $є$ інформаційно виправданим, виходячи з глобальної необхідності побудови перспективного майбутнього на грунті кращих традицій української минувшини.

Своєчасність та доцільність аналізу окресленої тематики актуалізована змістом чинної нормативно-пра- 
вової бази та фундаментальністю завдань розбудови національної школи на засадах суб'єктоцентризму, що передбачає глибинність переосмислення ролі особистості в сучасному соціо- та культуротворенні.

Аналіз досліджень і публікацій. Фрагментарність дослідження окремих аспектів сформульованої проблематики знаходимо на сторінках праць окремих українських учених, зокрема, О. Сухомлинської, Т. Завгородньої, Н. Дічек, О. Вишневського та інших.

У межах заявленої проблематики автором виокремлено окремі дослідницькі завдання:

- окреслити значущість феноменологічного впливу на пожвавлення просвітницького руху досліджуваного періоду;

- деталізувати мінливість суспільно-політичних подій з урахуванням ключових особливостей феноменологічного функціонування;

- переосмислити уроки минулого в ретроспекції майбутнього освітнього реформування.

Виклад основного матеріалу дослідження. Збереження статусу "підвладних територій" за мінливого домінування керівних держав актуалізувало підтримання на проукраїнських теренах клімату ідеологічної невизначеності. Систематичний експорт "державотворних" осіб зі сторони Російської імперії, які працювали над тим, щоб понизити відсотковість впливу на українство самостійницьких ідей, сам по собі підсилював дискомфортні умови соціокультурного буття. Такі коливальні хвилі торкалися і берегів Правобережжя, населення якого віддавало перевагу україномовному спілкуванню.

Чіткість суспільно-масового розуміння того, що загальнонаціональне начало перевищує шовіністичне "жало", змушувало провладні структури діяти ще більш рішуче і без упередження. Проте реалізація запланованого потребувала відповідних ресурсних витрат (зокрема, як людських, так і часових). Якщо часова витратність регулювалася керівними структурами доволі складно, то людська потребувала систематичного втручання, контролю та корелювання. Ідеальними носіями імперської "прополітики" з точки зору тогочасного керівництва були службовці, педагоги та духівники. Рівень їх впливу на суспільні маси став доволі високим, а продуктивність співпраці 3 територіальними громадами було важко переоцінити. На таких свідомих персон покладалося надскладне соціокультурне завдання - переорієнтувати свідомість широких суспільних мас у "правильне русло". Таким "правильним" вважалося загальноімперське, а всі суперечливі моменти викреслювалися з порядку денного, що засвідчувало про надмірну посиленість владних намагань створити бутафорний ландшафт соціокультурного успіху.

У таких неоднозначних умовах суспільно-політичного буття справжня елітність педагогічного складу приховувалася у функціональному та ціннісному потенціалі щоденних реалій. Функціональний потенціал повноцінно виявлявся у виконанні навчально-виховних функцій на місцях та вирізнявся чіткою суб'єкт-суб'єктною співпрацею. Ціннісний потенціал був наслідком "дієздатності" функціонального, що віддзеркалювалося у ціннісних орієнтирах навчально-виховного процесу, які "торкалися" кожної особистості вихованця.

У досліджуваний період світоглядний ракурс розуміння елітності став дотичним до феномена "інтелігенція", який інтегрував у своєму сутнісному наповненні культурнодуховну "авангардність" цілих поколінь та епох. Визначальність впливу педагогічної спільноти досліджуваного періоду на просвітницьке зростання проукраїнських регіонів доволі помітна, ураховуючи ініціативність відкриття нових освітніх осередків, цілеспрямованість поширення україномовної літератури та інші прогресивні кроки назустріч національному відродженню. Продуктивність педагогічної співпраці із суб'єктами пізнання підсилювалася завдяки тісній внутрішньогалузевій співпраці, репрезентованій на рівні розгалуженої соціокультурної інкорпорації.

Після того, як населення Правобережжя поволі звикало до певних геополітичних трансформацій, проімперський механізм закріплював свої "привілейовані" позиції на Лівобережжі. Освіта залишалася важливим "концентром" загальнодержавного реформування, оскільки виховання "вірних підданих" потребувало залучення необхідних ресурсів.

3 метою недопущення "детонації" польських сил на Правобережжі російська влада прийняла рішення здійснювати цілеспрямова- ний тиск на місцевий соціум у двох напрямах:

а) суспільно-політичному - зорієнтованому на упорядкування життєдіяльності підконтрольних територій відповідно до норм проімперського законодавства;

б) соціокультурному - націленому на утвердження "панівних" традицій контролюючої сторони 3 метою придушення проблематичності звучання національного питання.

Своєрідним ядром соціокультурного напряму реформування залишалася освіта, яка мала озброїти суб'єктів пізнання не лише комплексом знань, умінь і навичок, але і спрямувати на досягнення соціокультурного оптимуму. На початку століття польський елемент Правобережжя мав значно міцніші позиції у регіоні, аніж діюче керівництво. У матеріалах джерельної бази зазначається, що поляки впливали на місцеве українське населення "...засобами розуму, релігії, освіти..." (Польский катехизис, 1885, с. 216). Посприяли утвердженню польських позицій і ліберальні погляди діючого російського очільника Олександра I, котрий досить толерантно вибудовував регіональну політику стосовно національних меншин.

Субкомфортність соціокультурного клімату в регіонах у перші роки XIX ст. підсилювалася і створенням у межах виконавчої влади нової структурної одиниці- Міністерства народної освіти, якому підпорядковувалися усі освітні заклади імперії. Варто зауважити, що до справи освітнього реформування залучались і представники польської національної меншини. Можемо припустити, що однією з причин довірливого ставлення діючого в той час імператора до місцевої польської знаті була їх авторитетність серед аристократичних кіл того часу та феноменальні організаторські здібності. 3 метою підсилення аргументованості викладеної позиції варто згадати таких знатних постатей того часу, як С. Потоцький, Г. Стройновський, А. Чарторийський. Слід зазначити, що кожен з них приклав чимало зусиль для того, щоб підвищити рівень розвитку освіти та освіченості в окремих проукраїнських регіонах перебування польських громад.

Паралельно до процесу сполячення реалізовувалася й політика русифікації, що суміжним чином передбачало відповідні фінансові вит- 
рати на утвердження "правильної" освітньої політики, яка націлювалася на підтримання домінуючих у регіонах позицій впливу.

Для обидвох зацікавлених сторін, як російської, так і польської, українське питання поставало доволі гостро, оскільки можливі прояви національно-патріотичних позицій на місцях послужили черговим випробуванням у боротьбі за утвердження лідируючих позицій. Ключовим завданням на території приєднаних регіонів було витіснення наявних "ідеологічних конкурентів" з допомогою залучення пріоритетних важелів адміністративно-державного впливу (Дудка, 2017).

У таких соціокультурних умовах під пильним наглядом діючої влади залишалися освітяни, до яких висувалися доволі високі вимоги не лише професійно-кваліфікаційного змісту. За задумом пануючих кіл, основним завданням освітян було створення таких навчально-виховних умов, які актуалізували б викорінення загальнонаціонального стрижня. Ці задуми доволі "виправдані", ураховуючи високий рівень авторитетності педагогічної спільноти серед широких суспільних мас. Проте чимало освітян того часу перебувало у "стані" прихованої конфронтації стосовно тодішнього режиму. Протягом досліджуваного періоду чисельність непідвладних політичним настроям освітян зростала, виходячи з пріоритетності національного питання, що неухильно позначалося на зростанні рівня самосвідомості серед широких суспільних мас (Дудка, 2017).

Усі небайдужі до українського питання освітяни об'єднувалися у своєрідні соціокультурні інкорпорації, значущість яких приховувалася на рівні двох основоположних детермінант. Зокрема, перша була ціннісною, засновувалася на підтриманні відповідного рівня морального і патріотичного виховання, які були доволі значущими у формуванні стрижня національної самосвідомості; другою - функціональна, яка репрезентувала освітянина в ролі ключової фігури для реалізації навчально-виховного плану. Такий дуалізм став основоположним на площині соціокультурного буття підростаючого українства.

Феномен соціокультурної інкорпорації освітян вирізнився у суспільно-політичних умовах визначеного періоду. Узагальнені штрихи культу- ротворчої активності таких інкорпорацій були, по суті, двовимірними, оскільки торкалися вітчизняних та іноземних теренів, що віддзеркалювалося у налагодженні тісної міжособистісно-галузевої співпраці на рівні різних соціальних інститутів. Певні закономірності культуротворчої активності освітян прослідковувалися переважно в:

- розширенні кількості соціальних контактів усупереч існуючим державним кордонам;

- примноженні чисельності освічених на територіях визначених адміністративно-територіальних одиниць;

- популяризації розумової (інтелектуальної), педагогічної, науководослідницької, творчої діяльності.

Дієвість впливу соціокультурної інкорпорації освітян на суспільні маси проукраїнських регіонів була настільки фундаментальною, що це викликало бурю занепокоєнь серед політичних кіл того часу. Український історик В. Верига зазначив, що протягом XIX ст. польська знать, намагаючись підтримати свої авторитетні позиції на Правобережжі, працювала в напрямі "...енергійного збереження і закріплення своєї влади та своїх впливів..." (Верига, 1996, с. 31). Вочевидь, саме викладена вище ідейність була покладена в основу освітньої політики Віленського навчального округу, який на поч. XIX ст. поєднав у своєму складі три проукраїнські губернії - Київську, Волинську та Подільську (Сірополко, 2001). Пробуючи змалювати полоністичні вектори освітньої політики чинного керівництва, вітчизняний історик зауважив, що губернські "...школи зробилися розсадниками польської культури й польського патріотизму..." (Щербак, 2005, с. 107). Не викликає сумнівів і той джерелознавчий фактаж, що протягом першого тридцятиріччя XIX ст. Правобережжя послужило епіцентром полонізаційного впливу, а ступінь політичної інтеграції цієї території до Російської імперії не відповідав істинному показнику соціокультурної інтегрованості зазначених земель.

На території Правобережжя процес ополячення поступово змінювався на обрусіння. Варто підкреслити, що перехід від неформального ополячення частково провокувався польським повстанням 1830-1831 pр. (Сірополко, 2001). Ця історична подія позначилася і на подальшому векторі розвитку освіти, зокрема, відкритті Університету св. Володимира (1834 р.) (Сірополко, 2001). Представники професорсько-викладацького складу столичного університету володіли достатньо прогресивним багажем знань, а тому їхня тісна співпраця зі студентством пробуджувала в останніх значний інтерес до просвітницьких традицій загалом (Дудка, 2017).

Відкриття класичного університетуна території Київщини все ж не знизило рівня конфліктності російської влади стосовно аполітичних сил. Намагання призупинити будь-які ноти національного питання породжували чергові прояви насильницької денаціоналізації, яка торкалася кожного освітнього осередку, що юридично підпорядковувався владним структурам.

Прихід до влади нового консервативного імператора, який замінив свого попередника - ліберала Олександра I, у джерелознавчих матеріалах досить відверто синонімізувався 3 появою на геополітичній арені "...головного "внутрішнього" ворога" для підвладної інтелігенції (Льсенко, 2006, с. 80).

Загалом імперська влада "...будувала устрій університетів на буквалізмі офіційної ідеології", який повністю виключав ідею національної самостійності (Зінченко 1994, с. 382). Саме тому українознавчо зорієнтовані просвітницькі традиції діючий уряд розглядав як велику небезпеку, що може призвести до руйнації імперської конструкції.

Проте і в таких мінливих умовах не варто недооцінювати значущості проукраїнсько налаштованих представників соціокультурної інкорпорації освітян, які приклали чималих зусиль для збереження національного стрижня, підтримання патріотичного духу в колі наявних суспільних мас регіонів. Сучасний дослідник так охарактеризував діяльність прогресивних освітян того часу: ". . .вона набула громадського звучання, вливаючись у загальний процес українського національного відродження... пробуджувала історичну пам'ять та національну свідомість, знайомила i виховувала суспільство..." (Журба, 1993, с. 149-150).

Для проукраїнсько налаштованих освітян такі суспільно-політичні хвилі були, з одного боку, доволі розосереджуючими, а з іншого - консолідуючими. Розосереджувальний 
підтекст певною мірою виявлявся у роздвоєності керівних впливів - неформального (полонізаційного) та формального (проросійського); консолідуючий - доволі виразно віддзеркалювався в ідеологічній протидії соціокультурної інкорпорації освітян існуючим політико-ідеологічним обставинам. Високий рівень соціальної згуртованості на місцях уможливив надалі розгортання проукраїнських просвітницьких проєктів, які сколихнули вітчизняні терени ідейною прогресивністю.

В умовах перехресного конфронтаційного режиму "ополячення - русифікація" представники свідомої проукраїнської інтелігенції намагалися знайти найбільш оптимальне рішення для виходуз денаціоналізаційного "простору". Справжньою перешкодою для реалізації окресленого вище "контрплану" став систематичний "імпорт" проросійських елементів на ключові посади на місцях, що дедалі більше віддаляло все українство від досягнення бажаного соціокультурного оптимуму. Черговою перешкодою виявилось і те, що політика домінуючого шовінізму розмивала регіональні потреби на фоні загальноімперських запитів та зоріснтовувалася на всебічне підкорення і закріпачення. Тодішня влада доклала чималих зусиль для того, щоб переформатувати тогочасну освіту та науку відповідно до поточних політичних інтересів й економічних потреб; звузити навчально-виховні завдання до обмеженого перелікузнань, умінь і навичок, прийнятних для правлячих кіл.

У рамках такої безкомпромісної боротьби відбувалося справжнє загартування українства, яке підтримувала соціокультурна інкорпорація освітян шляхом реалізації низки просвітницьких проєктів. Характерною особливістю останніх було те, що вони націлювалися на поширення у колах широких суспільних мас критичного ставлення до діючого режиму, прихильного підходу до славетного минулого та оптимістичного бачення національного визволення. Таке тенденційно-проєктне тріо підживлювало відродження патріотичної ідейності, поглиблювало значущість етнічного питання українства та продукувало перехід на новий рівень усвідомленого націєтвірного буття.

Успіх просвітницьких проєктів соціокультурної інкорпорації освітян у боротьбі з різнокультурними впливами забезпечувався особистісним потенціалом самих представників високоінтелегентної спільноти, котра досить виразно демонструвала свої національні погляди та переконання (Дудка, 2016). Такі освітяни працювали над збагаченням культурної скарбниці, збереженням регіональної унікальності та пробудженням широких суспільних мас.

Проте окреслення царським урядом консервативних кордонів не стало перешкодою на шляху розвитку просвітництва в тогочасних реаліях. Існуюча політична ситуація, навпаки, спровокувала підвищення інтересу громадсько-педагогічної еліти вийти за межі "критичного" режиму функціонування, знайти нові можливості реалізацій цілісного проєкту просвітництва.

Висновки та перспективи подальших досліджень. 3 викладеного вище можемо зробити висновок, що перше тридцятиріччя XIX століття позначилося на сторінках історії чергуванням ліберальних і консервативних реформ, що посилювало актуальність національного питання. Для розвитку досліджуваного феномена даного історичного періоду характерною була стійка поступальна тенденція, яка вибудовувалася на основі національних традицій і цінностей та орієнтувалася на реалізацію ідеї особистісного саморозвитку.

Перспективи подальших розвідок вбачаємо в дослідженні персоніфікованої спадщини освітян, котрі, об'єднуючись у неформальні соціокультурні інкорпорації, заклали міцний фундамент подальшого освітнього та наукового поступу регіону.

\section{СПИСОК ЛІТЕРАТУРИ}

Верига, В. (1996). Нариси з історії України (кін. XVIII - поч. XX ст.). Львів : Світ.

Дудка, Т. Ю. (2016). Внесок науково-педагогічної еліти в українське національне відродження (20-ті pp. XX ст.). Гірська школа Украӥнських Карnam, 15, 148-152.

Дудка, Т. Ю. (2017). Просвітницький туризм як історико-педагогічний феномен. Київ-Херсон : ФОП Гринь Д. С.

Журба, О. І. (1993). Київська археографічна комісія. 1843-1921. Haрис історії і діяльності. Київ : Нау- кова думка.

Зінченко, А. А. (1994). Церковне землеволодіння в політиці царизму на Правобережній Україні наприкінці XVIII - першій половині XIX ст. Київ.

Лысенко, Л. М. (2001). Губернаторы и генерал-губернаторы Российской империи (XVIII - начало XX в.). Москва: МПГУ.

Польский катехизис, (1885) Польское дело по отношению к Западной России. Сборник статей, Вып 1.

Сірополко, С. (2001). Історія освіти в Україні. Львів : Афіша.

Щербак, Н. О. (2005). Національне питання в політиці царизму на Правобережній Україні (кінець XVIII - початок ХХ століття). Київ : ПЦ"Ризографіка".

\section{REFERENCES}

Veryga, V. (1996). Narysy z istoriyi Ukrayiny (kin. XVIII - poch. XX st.). Lviv: Svit [in Ukrainian].

Dudka,T. Yu. (2016). Vnesok naukovo-pedagogichnoyi elity $v$ ukrayinske nacionalne vidrodzhennya (20-ti rr. XX st.). Girska shkola Ukrayinskyh Karpat, 15, 148-152 [in Ukrainian].

Dudka, T.Yu. (2017). Prosvitnyczkyj turyzm yak istoryko-pedagogichnyj fenomen. Kyiv-Herson : FOP Gryn D. S. [in Ukrainian].

Zhurba, O. I. (1993). Kyyivska arheografichna komisiya. 1843-1921. Narys istoriyi $i$ diyalnosti. Kyiv : Naukova dumka [in Ukrainian].

Zinchenko, A. A. (1994). Cerkovne zemlevolodinnya v polityci czaryzmu na Pravoberezhnij Ukrayini naprykinci XVIII - pershij polovyni XIX st. Kyiv : D. S. [in Ukrainian].

Lusenko, L.M. (2001). Gubernatoru y general-gubernatoru Rossyjskoj imperyy (XVIII - nachalo XX v.). Moskva : MPGU [in Russian].

Polskyj katehyzys (1885). Polskoe delo po otnoshenyyu k Zapadnoj Rossyy: Sbornyk statej. Moskva : V. S. [in Russian].

Siropolko, S. (2001). Istoriya osvity vUkrayini. Lviv: Afisha [in Ukrainian].

Shherbak, N. O. (2005). Nacionalne pytannya $\mathrm{v}$ polityci czaryzmu na Pravoberezhnij Ukrayini (kinecz XVIII - pochatok XX stolittya). Kyiv : PCz "Ryzografika" [in Ukrainian].

Стаття надійшла 29.03.2020 p. 